\title{
INTERPRETAÇÃO DE ANOMALIAS DE GEÓIDE E AR-LIVRE DA MARGEM CONTINENTAL SUL DO BRASIL, ESCUDO RIO-GRANDENSE E SE DO CONE DO RIO GRANDE
}

\author{
Emilson Pereira Leite \\ Orientadora: Dra. Naomi Ussami (IAG-USP) \\ 60 p. - Dissertação (Mestrado) \\ Defesa: 18/4/2000
}

\section{RESUMO}

Os dados de gravimetria marinha convencional e das missões de altimetria por satélite GEOSAT/ERM e SEASAT permitiram o cálculo de modelos de anomalia ar-livre e do geóide na região compreendida entre $25^{\circ}-40^{\circ} \mathrm{S}$ e $25^{\circ}-65^{\circ} \mathrm{W}$, através da colocação por mínimos quadrados, com resolução nominal de 10'. Esta região engloba importantes feições tectônicas como a Elevaç̧ão do Rio Grande, o Platô de São Paulo, a Bacia de Pelotas e 0 Cone do Rio Grande. São observadas anomalias do geóide positivas sobre essas principais feições. A variação da densidade em função da profundidade indica um importante afinamento crustal sob o Escudo Rio-Grandense e a Bacia de Pelotas. Este resultado, integrado com dados de traço de fissão sobre rochas do embasamento na margem continental emersa e com a estratigrafia da Bacia de Pelotas, sugere um soerguimento e uma erosão neste segmento da litosfera continental, decorrentes do aparecimento de uma anomalia térmica que durou até $30 \mathrm{Ma}$. A mesma estrutura termal é observada na Elevação do Rio Grande onde a litosfera ocênnica tem idade de $80 \mathrm{Ma}$. Como resultado do soerguimento e da erosão da margem continental, uma grande quantidade de sedimentos foi depositada nas partes afastadas da costa e no Cone do Rio Grande. A inversão das anomalias ar-livre numa bacia à sudeste do Cone do Rio Grande permitiu estimar as densidades e o formato estrutural dessa bacia. A densidade da camada sedimentar varia entre 2,3 a 2,5 g/ $\mathrm{cm}^{3}$. A espessura da bacia, inferida através da variação de densidade, é cerca de $3,0 \mathrm{~km}$.

\section{ABSTRACT}

Shipborne and continental gravity data were integrated with GEOSAT/ERM and SEASAT satellite altimetry data in order to calculate free-air and geoid anomalies in the region between $25 / 40^{\circ}$ S and $25 / 65^{\circ} \mathrm{W}$, using Least Square Collocation technique in a $10^{\prime}$ resolution grid. This region includes several tectonic features such as the Rio Grande Rise, São Paulo Plateau, Pelotas Basin and Rio Grande Cone. Geoid highs are observed over the main tectonic features. Density distribution with depth indicates an important crustal thinning under the Uruguay/Rio-Grandense Shield and Pelotas Basin. This result integrated with a few fission-track ages of the onshore continental margin basement and with Pelotas basin stratigraphy suggests an uplift and erosion in this segment of the lithosphere as a result of a thermal anomaly which lasted until $30 \mathrm{Ma}$. The same thermal structure is observed in the Rio Grande Rise, where the oceanic lithosphere is $80 \mathrm{Ma}$ old. As a result of continental margin uplift and erosion large amounts of sediments were deposited offshore and in the Rio Grande Cone. Free-air anomaly inversion shows a basin southeastern of Rio Grande Cone. This gravity derived upper crustal model allowed to estimate densities and the structural shape of this basin. Densities of the sediments range between 2.3 and $2.5 \mathrm{~g} / \mathrm{cm}^{3}$. The maximum thickness of the basin is about $3.0 \mathrm{~km}$. 